\title{
Growth and shrinkage of Antarctic krill Euphausia superba from the Indian Ocean sector of the Southern Ocean during summer
}

\author{
Stephen Nicol, Martin Stolp, Tonia Cochran, Pia Geijsel, Judi Marshall
}

Australian Antarctic Division, Channel Highway, Kingston, Tasmania, 7050, Australia

\begin{abstract}
Growth rates of Antarctic krill Euphausia superba Dana in the Indian Ocean sector of the Southern Ocean were measured in 4 summers. Growth rate was measured using an instantaneous growth rate' technique which involved measuring the mean change in length of the uropods at moulting. In the first $4 \mathrm{~d}$ following collection mean growth rates ranged from 0.35 to $7.34 \%$ per moult in adults and 2.42 to $9.05 \%$ in juveniles. Mean growth rates of adult and juvenile krill differed between areas and between the different years of the investigation. When food was restricted under experimental conditions, individual krill began to shrink immediately and mean population growth rates decreased gradually, becoming negative after as little as $7 \mathrm{~d}$. Populations of krill which exhibited higher initial growth rates began to shrink later than those which had initially been growing more slowly.
\end{abstract}

\section{INTRODUCTION}

Antarctic krill Euphausia superba Dana shrink in the laboratory if maintained in conditions of low food availability. The ability to grow smaller with each moult was proposed as a mechanism whereby this species might survive a long period of food limitation such as during the Antarctic winter (Ikeda \& Dixon 1982). Overwinter shrinkage of krill would complicate the relationship between size and age and as a result, a number of studies have investigated alternative methods for ageing Antarctic krill (Ettershank 1984, Rosenberg et al. 1986, Nicol et al. 1991\}. Recent studies have demonstrated that E. superba individuals may be shrinking in the field during winter (Quetin \& Ross 1991) and that mean shrinkage of a population over the period of a year could be demonstrated in the laboratory (Nicol et al. 1991). It is still uncertain, however, whether shrinkage naturally occurs to the extent that it affects the population size-structure in such a way as to cause errors in determining the numbers of age classes present.

There are indications from some studies that have involved repeated sampling of discrete populations that shrinkage may occur during winter. Fjord populations of northern species of euphausiids have shown a decrease in mean size during winter (Falk-Petersen 1985) and a similar decrease in mean size of Euphausia superba was detected in a population in Admiralty Bay (South Shetland Islands, Antarctica) which was attributed to differential size-related mortality rates (MCClatchie et al. 1991).

There is always some doubt when examining timeseries data from krill populations in the ocean because of the difficulty of ensuring that the sequential samples have been taken from a single population. For this reason measurements of 'instantaneous' growth rates may be the best approach to determine whether the individuals in a population are growing or shrinking at any particular time and these can be used to interpret any changes in observed size frequencies that are observed over longer time scales. Buchholz et al. (1989) suggested using the growth increment - the percentage increase in body length at moult - as an indicator of growth in krill. Quetin \& Ross (1991) outlined a methodology, based on such growth increments, for the measurement of instantaneous growth rates and demonstrated both shrinkage and growth in freshly caught krill. We used this methodology to demonstrate differential growth rates between adult and juvenile 
krill during summer. The technique was also extended to examine the effect over time of food limitation on the mean growth rate.

\section{MATERIALS AND METHODS}

Live Antarctic krill were collected from the Prydz Bay Region off Antarctica on 4 occasions. A pilot study was carried out in 1990 using krill collected on 29 January at $67^{\circ} 19^{\prime} \mathrm{S}, 72^{\circ} 02^{\prime} \mathrm{E}$. Full-scale experiments were carried out in 1991 on 3 occasions: 29 January (position: $\left.66^{\circ} 33.3^{\prime} \mathrm{S}, 74^{\circ} 50.7^{\prime} \mathrm{E}\right), 11$ February $\left(65^{\circ}\right.$ $\left.32.0^{\prime} \mathrm{S}, 69^{\circ} 05.0^{\prime} \mathrm{E}\right)$ and 25 February $\left(66^{\circ} 46.0^{\prime} \mathrm{S}, 73^{\circ}\right.$ $\left.38.0^{\prime} \mathrm{E}\right)$ and again on 23 February $1992\left(64^{\circ} 60.0^{\prime} \mathrm{S}, 77^{\circ}\right.$ $\left.37.6^{\prime} \mathrm{E}\right)$. Collection was by a RMT 8 net which was opened in the top $20 \mathrm{~m}$ of the water column and allowed to drift at $<1 \mathrm{knot}$ for $10 \mathrm{~min}$, closed and rapidly brought on board. Live krill were randomly collected from the catch for each experiment and individuals (148 in the first year's experiments and 117 in the second year's experiment) were placed in 2 I clear plastic jars containing freshly collected surface seawater. Water was changed weekly; no additional food source was added and the weekly addition of fresh, unfiltered seawater represented an extremely dilute and sporadic food supply. The jars were maintained at $0^{\circ} \mathrm{C}$ (the ambient surface seawater temperature was between -1 and $1{ }^{\circ} \mathrm{C}$ ) in the dark and were checked twice daily for moults. If the krill had moulted the animal and the exuviae were removed and the length of the uropods on both were measured. The percentage change in size at moult of each uropod was noted and the growth rate was expressed as the mean percentage change of both uropods. If one uropod was damaged, then the measurement of the undamaged uropod was used to calculate growth.

Comparable measurements were taken on 2 earlier occasions from juvenile Euphausia superba maintained under similar conditions in 1988. One population had been sampled on 14 February 1988 off Wilkes Land, $65^{\circ} 05.0^{\prime} \mathrm{S}, 109^{\circ} 44.4^{\prime} \mathrm{E}$ and the second on 20 February 1988 in the Prydz Bay region, $66^{\circ} 52.0^{\prime} \mathrm{S}$, $73^{\circ} 09.0^{\prime} \mathrm{E}$. These data were re-analysed to provide growth rates from 2 areas in 1 yr which could be compared to the measurements taken in 1990-1992.

Instantaneous growth rate experiments usually only last 4 d (Quetin \& Ross 1991 and pers. comm.). Experiments of longer duration begin to reflect laboratory rather than field conditions. We held all krill until they moulted, thus allowing us to observe not only the initial growth rates which were representative of the field conditions but also the growth rate of krill which had experienced different periods (up to 32 d) of imposed food limitation. Experimental conditions represented food limitation though not total absence of food. Some food particles were certainly added with the weekly water changes. Maximal surface chlorophyll a (chl a) concentrations in the Prydz Bay region during summer 1991 were $3 \mu \mathrm{gl}^{-1}$ (S. Wright unpubl. data) so krill would not have received more than $6 \mu \mathrm{g}$ chl a $w_{k}{ }^{-1}$. Clarke \& Morris (1983) estimated that krill require $300 \mathrm{ng}$ chl $a \mathrm{~h}^{-1}$ to support metabolism and growth so the maximum amount of food supplied during water changes would only sustain metabolism and growth for $20 \mathrm{~h}$. The krill were, therefore, considered to be in conditions of extreme food limitation for the duration of these experiments.

Table 1. Euphesia superba. Sizes and percentage uropod length increases in adult and juvenile Antarctic krill during the first $4 \mathrm{~d}$ following capture. Sample sizes and standard deviations are in parentheses. No adults were examined in 1988 and no juveniles were examined during 1992

\begin{tabular}{|c|c|c|c|c|}
\hline Date & $\begin{array}{l}\text { Mean adult uropod } \\
\text { length (mm) }\end{array}$ & $\begin{array}{c}\text { Mean juvenile } \\
\text { uropod length }(\mathrm{mm})\end{array}$ & $\begin{array}{l}\text { Mean \% adult } \\
\text { growth }\end{array}$ & $\begin{array}{c}\text { Mean \% juvenile } \\
\text { growth }\end{array}$ \\
\hline Feb 1988 (Expt 1) & - & ( $\mathrm{n}=24, \mathrm{SD}=0.65)$ & - & $\begin{array}{c}3.87 \\
(\mathrm{n}=26, \mathrm{SD}=4.93)\end{array}$ \\
\hline Feb 1988 (Expt 2) & - & $(\mathrm{n}=20, \mathrm{SD}=0.33)$ & - & $\begin{array}{c}2.42 \\
(\mathrm{n}=20, \mathrm{SD}=4.56)\end{array}$ \\
\hline Jan 1990 & $\begin{array}{c}5.96 \\
(\mathrm{n}=7 . \mathrm{SD}=0.41)\end{array}$ & - & $\begin{array}{c}4.44 \\
(\mathrm{n}=7, \mathrm{SD}=4.62)\end{array}$ & - \\
\hline Jan 1991 (Expt 1) & $\begin{array}{c}6.25 \\
(\mathrm{n}=9, \mathrm{SD}=0.86)\end{array}$ & $\begin{array}{c}3.99 \\
(\mathrm{n}=8, \mathrm{SD}=0.47)\end{array}$ & $\begin{array}{c}5.56 \\
(\mathrm{n}=9, \mathrm{SD}=5.67)\end{array}$ & $\begin{array}{c}9.05 \\
(\mathrm{n}=9, \mathrm{SD}=3.56]\end{array}$ \\
\hline Feb 1991 (Expt 2) & $\begin{array}{c}5.97 \\
(\mathrm{n}=15, \mathrm{SD}=0.49)\end{array}$ & $\begin{array}{c}4.05 \\
(n=5, S D=1.07)\end{array}$ & $\begin{array}{c}2.04 \\
(\mathrm{n}=15, \mathrm{SD}=2.98)\end{array}$ & $\begin{array}{c}4.1 \\
(\mathrm{n}=5, \mathrm{SD}=3.33)\end{array}$ \\
\hline Feb 1991 (Expt 3) & $\begin{array}{c}6.43 \\
(\mathrm{n}=10, \mathrm{SD}=10)\end{array}$ & $\begin{array}{c}3.92 \\
(\mathrm{n}=6, \mathrm{SD}=0.25)\end{array}$ & $\begin{array}{c}0.35 \\
(n=10, S D=4.25)\end{array}$ & $\begin{array}{c}4.01 \\
(\mathrm{n}=7, \mathrm{SD}=3.77)\end{array}$ \\
\hline Feb 1992 & $\begin{array}{c}4.77 \\
(\mathrm{n}=12, \mathrm{SD}=0.26)\end{array}$ & - & $\begin{array}{c}7.34 \\
(\mathrm{n}=14, \mathrm{SD}=3.63)\end{array}$ & - \\
\hline
\end{tabular}




\section{RESULTS}

Most krill that moulted during the first $4 \mathrm{~d}$ following collection grew and the mean length increase at moult ranged from 0.35 to $9.05 \%$ (Table 1 ).

Two experiments were relatively short term. The 1990 experiment ran for $5 \mathrm{~d}$ with growth rates ranging between $-2 \%$ and $9.35 \%$ length increase per moult. Expt 1 in 1991 ran for $8 \mathrm{~d}$ and the mean daily growth rate remained positive $(0.75$ to $7.5 \%$ per moult in adults and 5.4 to $12.0 \%$ in juveniles) although growth rates of individual krill ranged from -4.2 to $15.7 \%$.

Five experiments examined the longer term effects of food limitation on growth. Expt 1 in 1988 lasted $22 \mathrm{~d}$
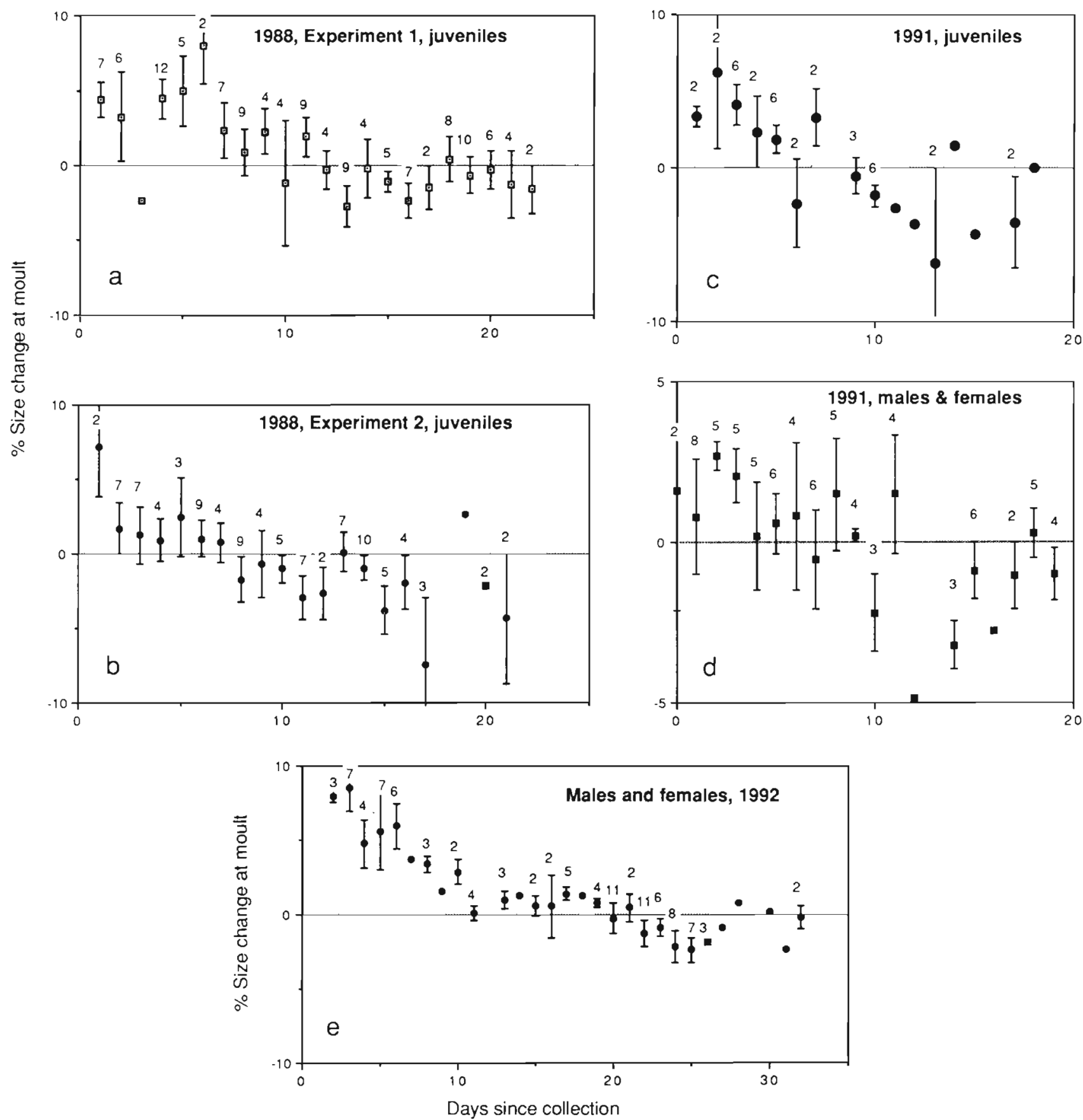

Fig. 1. Euphausia superba. Growth rate of Antarctic krill shown as mean percentage change in uropod length per day ( \pm 1 SE) Sample size given above error bar. (a) Juvenile krill in 1988, Expt 1. (b) Juvenile krill in 1988, Expt 2. (c) Juvenile krill in 1991, Expts 2 \& 3 combined. (d) Adult krill in 1991, Expts 2 \& 3 combined. (e) Adult krill in 1992 experiment. Note differences in scale of $x$ - and $y$-axes 
and Expt 2 in 1988 lasted $21 \mathrm{~d}$. In both experiments the mean initial growth rate (the growth rates during the first $4 \mathrm{~d}$ following collection) was positive but the population began to demonstrate net shrinkage after 8 to $12 \mathrm{~d}$ under the experimental conditions (Fig. 1a, b). The mean sizes and mean initial growth rates of juveniles from the 2 areas sampled in 1988 were not significantly different (sizes: $t=1.03, \mathrm{df}=46, \mathrm{p}=0.31$, growth rates: $t=1.02, \mathrm{df}=44, \mathrm{p}=0.31$ ).

Expts 2 \& 3 in 1991 lasted for 19 and 14 d respectively and the mean daily growth rates in both experiments followed a similar pattern to those in the 1988 experiments (Fig. 1c, d).

The single experiment in 1992 lasted $32 \mathrm{~d}$ and again the pattern of initial mean positive growth followed by a decrease in the mean growth rate and eventual shrinkage of the population was repeated (Fig. 1e)

The initial mean growth rates of all adult males and females in 1991 were not significantly different (males: mean $1.83 \%$, females: $2.94 \%, t=0.73$, dt $=32, \mathrm{p}=$ 0.47 ). Only 2 males moulted during the first $4 \mathrm{~d}$ in 1992 so sex-related differences were not examined. The mean initial growth rate of all juveniles in 1991 was significantly greater than that of all adults in 1991, the only year where comparable growth rates were available $(t=3.26$, df $=52, p<0.002)$. The mean initial growth rate of adults in 1992 was significantly larger than that of the mean initial growth rate of all adults from the 3 experiments in $1991(t=3.56, \mathrm{df}=46$, $p<0.001$ ). This difference may be a result of the

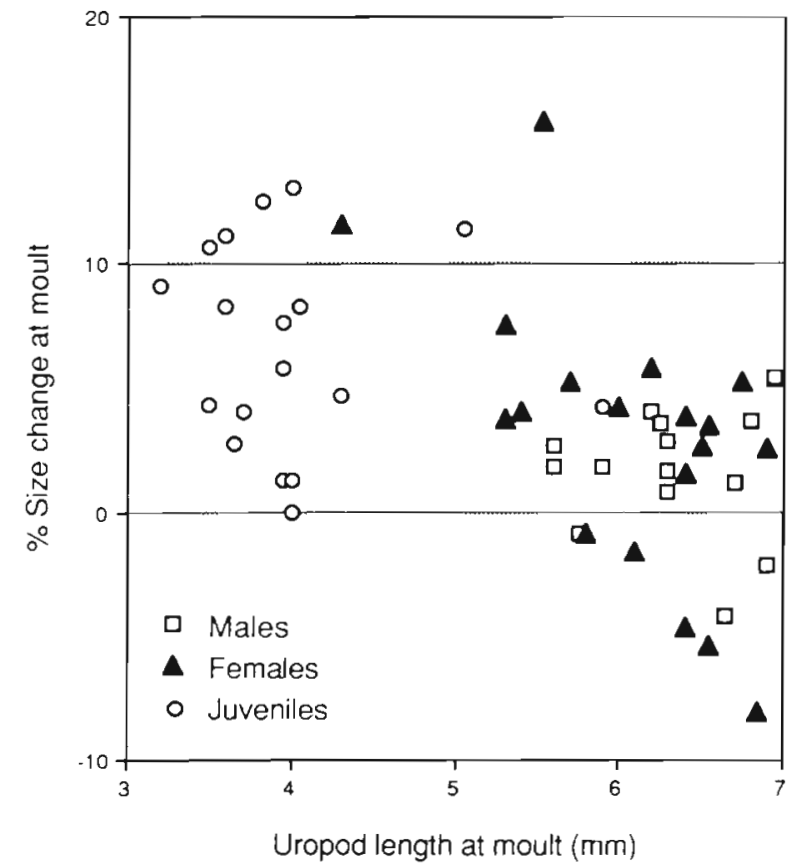

Fig. 2. Euphausia superba. Growth rates (\% size change) of all juvenile, male and female Antarctic krill in the first $4 \mathrm{~d}$ following collection in 1991 plotted against krill size smaller size of the adults collected during 1992 which grew at similar rate to the juveniles from 1991, although they were significantly larger $(t=3.065$, df $=32$, $\mathrm{p}<0.004)$

Individual krill began to shrink immediately following capture in 1991, in the second day in both experiments during 1988 and in 1990, and after 5 d in 1992 Shrinkage in the mean length of the adult population began after $7 \mathrm{~d}$ in 1991 compared to $20 \mathrm{~d}$ in 1992 (Fig. 1). Juveniles in 1991 also rapidly entered a negative growth phase and negative mean growth rates were observed $6 \mathrm{~d}$ following capture.

Freshly caught krill exhibited a range of instantaneous growth rates (Fig. 2). Shrinkage within the first few days of capture was prevalent among adults in 1991 with 8 out of 34 krill demonstrating shrinkage during the first $4 \mathrm{~d}$ of the experiments. Large krill may also be growing fast when captured with some males and females in the largest size class exhibiting growth rates of greater than $5 \%$ per moult. This suggests a high degree of individual variability in growth rates in the natural population at any one time even in high summer.

\section{DISCUSSION}

The 'instantaneous growth rate' of freshly caught Antarctic krill in summer was highly variable but the mean initial growth rates were positive in each of the 7 experiments carried out between 1988 and 1992. The growth rate of Euphausia superba began to decline shortly following capture under the experimental conditions and after a period became negative in all 3 years in which longer-term experiments were carried out. In 2 years, the point at which negative growth occurred differed substantially. In 1992, the mean initial growth rates of adults were much higher and the period between capture and the onset of shrinkage was also much greater than in 2 of the experiments during 1991. This may indicate that the krill in the 1992 experiment were in better physiological condition than the krill collected in 1991. A preliminary analysis has indicated that the lipid content of krill preserved withun $5 \mathrm{~d}$ of collection was higher during 1992 when compared to 1991 (1991: mean $=15.5 \%$ dry $w t, n=5$; 1992: mean $=23.4 \%, \mathrm{n}=4 ; t=2.26, \mathrm{p}=0.06 \mathrm{f}$ which tends to support this suggestion. There is also an indication that populations of krill which have high initial growth rates begin to shrink later than populations which have a low initial growth rate. Further experimentation is required to investigate the relationship between the initial growth rate, the size of the krill, the ability to withstand shrinkage in the absence of food and the physiological conditions of the animals

After krill had spent a number of days in the absence 
of food, their growth rates began to decline. This time lag suggests that the actual process of growth had already taken place some time before ecdysis and that food deprivation during this stage did not affect the increase in length at moulting. This period corresponds to moult stage D3-4 which appears to be a preparatory stage before ecdysis (Nicol \& Stolp 1990) and is thought to be a non-feeding stage (Morris \& Priddle 1984). The decline in the growth rate after the first few days in captivity and the rapid onset of shrinkage suggests that krill have limited reserves from which they can draw to effect growth even in high summer.

Growth is measured in the instantaneous growth rate' method by changes in length at moult. The results that we present indicate that length increases can still occur even if food has been restricted for up to $19 \mathrm{~d}$. Krill would obviously begin to lose weight as soon as their food source is removed and thus weight changes accompanying starvation would be quite different from changes in linear dimensions. Krill growth, however, has usually been expressed in terms of increase in length and it is the effect that shrinkage might have on the size structure of the population which has led to the re-assessment of length-frequency analysis as a tool in krill population dynamics (Ettershank 1984). Using weight change as a measurement of growth is a more complex problem which has not yet been tackled on an individual animal basis.

Quetin \& Ross (1991), using the 'instantaneous growth rate technique' showed positive growth of adult Euphausia superba during the late summer and autumn with increases in body length at moulting of between 1.75 and $4.4 \%$. In winter they found shrinkage of between -0.16 and $-2.03 \%$ of body length at each moult. Their rates are similar to those exhibited by adults in our 1991 studies although the initial growth rates exhibited by the krill in 1992 are considerably higher. The results of their 'instantaneous growth rate' study like the results from ours are based on measurements from a relatively small number of animals. Unfortunately, the design of the experiment requires large numbers of animals of which only a small fraction will be used for actual measurements of initial growth rates. Since Antarctic krill moult every 20 to $30 \mathrm{~d}$ at $0^{\circ} \mathrm{C}$ (Buchholz 1991) only 1 in 20 to 1 in 30 krill will moult on any given day of the experiment. To improve on the sample size that we used for the initial growth rates, several hundred krill would have to be maintained individually on board ship for each experiment and this is difficult to achieve in practice.

Field estimates of summer growth rates in krill populations have been calculated from time series of length frequency data (Miller \& Hampton 1989). Only 2 studies have attempted to track changes in the mean length of krill populations over short periods of time.
Kanda et al. (1982) observed a change in mean size of a population of krill from 41.13 to $41.98 \mathrm{~mm}$ in $12 \mathrm{~d}$ corresponding to a daily change of $0.063 \mathrm{~mm}$. Over a $30 \mathrm{~d}$ moult cycle this would represent a size change at moult of ca $4.6 \%$ which is consistent with our measurements. Clarke \& Morris (1983) measured the modal length change of a population of krill sampled over a $6 \mathrm{~d}$ period and observed a $2 \mathrm{~mm}$ increase corresponding to a $0.33 \mathrm{~mm} \mathrm{~d}^{-1}$ increase. The krill in their study were ca $30 \mathrm{~mm}$ long, so for a $30 \mathrm{~d}$ moult cycle the percentage increase at moult would be $33 \%$, considerably higher than other estimates. Other studies have used data obtained from much more widely spaced sampling intervals which may introduce a degree of error since it is not known whether the same population is being sampled over time. McClatchie (1988) predicted growth rates of between 0.041 to $0.125 \mathrm{~mm} \mathrm{~d}^{-1}$ for adult and juvenile krill in Admiralty Bay during summer (ca 4.1 to $12.5 \%$ increase in length per moult, again assuming a $30 \mathrm{~d}$ moult cycle) which are similar figures to those derived from the instantaneous growth rate' methodology of Quetin \& Ross (1991). Rosenberg et al. (1986) calculated growth rates of between 0.117 and $0.179 \mathrm{~mm} \mathrm{~d}^{-1}$ for $30 \mathrm{~mm}$ krill (corresponding to ca 11.7 and $17.9 \%$ increase in length per moult assuming a 30 d moult cycle) from a reexamination of the 'Discovery' data.

The growth rates of Euphausia superba derived from laboratory have been summarised by Buchholz (1991) and a range of positive growth increments up to $21 \%$ per moult have been reported. Most of the laboratory growth studies have relied on measurements of length taken from consecutively moulted exoskeletons which gives a coarse scale picture of growth over a whole moult cycle. One laboratory study has used a version of the 'instantaneous growth rate' technique, measuring the length of the krill and their newly produced exuviae (Buchholz et al. 1989) and an average increase in length of $3.8 \%$ per moult was observed under conditions of high food availability.

Shrinkage has been shown in the laboratory for 5 species of euphausiids: Euphausia pacifica (Lasker 1966), E. superba (lkeda \& Dixon 1982), Meganyctiphanes norvegica (Buchholz 1985). Thysanoessa inermis (Dalpadado \& Ikeda 1989), Nyctiphanes australis (Hosie \& Ritz 1989); in fact there are no reports in the literature of laboratory studies on shrinking by euphausiids which have failed to demonstrate shrinkage. The capacity to shrink can thus be taken as a natural response by E. superba (and indeed, of euphausiids as a group) to sub-optimal feeding conditions, and shrinkage in the laboratory has been shown to have no adverse long-term effects on the animals' subsequent ability to grow and survive (Thomas \& Ikeda 1987). Ikeda (1985) also found that long-term food depriva- 
tion resulted in a relatively constant shrinkage rate of $0.033 \mathrm{~mm} \mathrm{~d}^{-1}$ (ca $-3.3 \%$ per moult cycle) in juvenile $E$. superba (Ikeda 1985) which is similar to the rate of shrinkage demonstrated by krill our short term study. Thus, krill can apparently achieve their maximal shrinkage rate within a matter of days of food limitation and can maintain this shrinkage rate over very long periods, up to $211 \mathrm{~d}$ (Ikeda \& Dixon 1982).

Studies which have demonstrated shrinkage by euphausiids have done so by observing their change in size over whole moult cycles. Growth has been assessed by measuring the difference in lengths of the uropods from consecutive moults so the minimum experimental interval has been one moult cycle. Our study, by examining the size change at moulting, has enabled us to document the ability of krill to shrink in response to restrictions in food supply which occur on timescales shorter than one moult cycle.

Winter is the period when food is most likely to be limiting and hence this is the period when overall shrinkage of krill populations would be likely to occur. Daly (1990) reported significant growth of larval Euphausia superba during winter in the marginal ice zone but there are few unequivocal data sets which demonstrate either growth or shrinkage of adult or larval Antarctic krill over winter. Kawaguchi et al. (1986) studied krill captured under the ice over winter. They showed that not only did the mean size of krill decrease but the size range of krill present became restricted over the winter. They also found little evidence of feeding in the water column, low chl a concentrations throughout the winter and oxygen consumption figures which corresponded to those of starving, shrinking krill (Ikeda \& Dixon 1982). McClatchie et al. (1991) also observed a decrease in mean size and a reduction in the size range of krill in samples taken over winter from Admiralty Bay. They demonstrated a cycle of size increase during summer and decrease during winter for adults and juveniles but attributed the differences they observed to differential size-related mortality rather than to starvation-induced shrinkage.

Mean shrinkage of populations of Antarctic krill has been demonstrated by using instantaneous growth rates measured during the winter (Quetin \& Ross 1991) and, in our study, in krill taken directly from the wild during summer which have been subjected to food deprivation for a relatively short period of time. 'Instantaneous growth rate' experiments give summer growth rate for populations of Euphausia superba which are similar to those obtained from other types of study. Winter 'instantaneous growth rate' experiments (Quetin \& Ross 1991), for which there are no really comparable data, suggest that shrinkage does occur and has the ability to significantly affect the mean size of the population.
Our study has indicated that there is considerable variation in the growth rate, as measured by the 'instantaneous growth rate' technique, with individual, ontogenetic and seasonal effects. The results, however, tally well with estimates of krill growth arrived at by different techniques and show patterns, such as faster growth by smaller krill, which are predictable from other studies. It is possible that the initial growth rate coupled with the length of the period between capture and the onset of shrinkage may give some indication of the nutritional condition of the krill at any one time. Further seasonal measurements of 'instantaneous growth rates' should include a wide range of sizes and maturity stages of krill from populations in different regions, and could be coupled with measurements of the available food supply and of the physiological condition of the krill.

Acknowledgements. We thank R. Ross and L. Quetin for providing us with advice and copies of their experimental protocol. We are grateful to G. Hosie and H. Marchant who made helpful comments on the manuscript.

\section{LITERATURE CITED}

Buchholz, F. (1985). Moult and growth in euphausiids. In Seigfried, W. R., Condy, P. R., Laws. R. M. (eds.) Antarctic nutrient cycles and food webs. Springer-Verlag, Berlin, p. $340-345$

Buchholz, F. (1991). Moult cycle and growth of Antarctic krill Euphausia superba in the laboratory. Mar. Ecol. Prog. Ser. 69: $217-229$

Buchholz, F., Morris, D. J., Watkins, J. L. (1989). Analysis of field moult data: prediction of intermoult period and assessment of seasonal growth in Antarctic krill Euphausia superba Dana. Antarct. Sci. 1: 310-306

Clarke, A., Morris, D. J. (1983). Towards an energy budget for krill: the physiology and biochemistry of Antarctic krill Euphausia superba. Polar Biol. 2: 69-86

Dalpadado, P., Ikeda, T (1989). Some observations on moulting, growth and maturation of krill (Thysanoessa inermis) from the Barents Sea. J. Plankton Res. 11(1): 133-139

Daly, K. L. (1990). Overwintering development, growth, and feeding of larval Euphausia superba in the Antarctic marginal ice zone. Limnol. Oceanogr. 35(7): 1564-1576

Ettershank, G. (1984). A new approach to the assessment of longevity in the Antarctic krill Euphausia superba. J. Crust. Biol. 4 Spec. issue no. 1. 295-305

Falk-Petersen, S. (1985). Growth of the euphausiids Thysanoessa inermis, Thysanoessa raschii, and Meganyctiphanes norvegica in a subarctic fjord. North Norway. Can. J. Fish. Aquat. Sci. 42: 14-22

Hosie G. W., Ritz, D. A. (1989). Body shrinkage in the subtropical euphausiid Nyctiphanes australis. J. Plankton Res. 11(3): 595-598

Ikeda, T (1985). Life history of Antarctic krill Euphausia superba: a new look from an experimental approach. Bull. mar. Sci. 37(2): 599-608

Ikeda, T., Dixon, P. (1982). Body shrinkage: a possible overwintering strategy of the Antarctic krill (Euphausia superba Dana). J. exp. mar. Biol. Ecol. 62: 1.43-151 
Kanda, K., Takagi, K. Seki, Y (1982). Movement of the larger swarms of Antarctic krill Euphausia superba population off Enderby Land during 1976-1077 season. J. Tokyo Univ. Fish. 68: 25-42

Kawaguchi, K Ishikawa, S., Matsuda, O. (1986). The overwintering of Antarctic krill Euphausia superba Dana under the coastal fast ice off the Ongul Islands in LutzowHolm Bay, Antarctica. Mem. Natn. Inst. Polar res. Spec. Is5. $44: 67-85$

Lasker, R. (1966). Feeding, growth, respiration and carbon utilization of a euphausiid crustacean. J. Fish. Res. Bd Can. 23: $1291-1317$

McClatchie, S. (1988). Food-limited growth of Euphausia superba in Admiralty Bay, South Shetland Islands, Antarctica. Cont. Shelf Res. 8 (4): 329-345

McClatchie, S., Rakusa-Suszczewski, S., Fileck, K. (1991). Seasonal growth and mortality of Euphausia superba in Admiralty Bay, South Shetland Islands, Antarctica. ICES J. mar. Sci. 48: 335-342

Miller, D. G. M., Hampton, I. (1989). Biology and ecology of the Antarctic krill (Euphausia superba Dana): a review. BIOMASS 9: $1-166$

Morris, D. J., Priddle, J. (1984). Observations on the feeding and moulting of the Antarctic krill Euphausia superba Dana in winter Br. Antarct. Surv. Bull. 65: 57-63

Nicol, S., Stolp, M. (1990). A refinement of the moult-staging technique for Antarctic krill (Euphausia superba). Mar. Biol. 104: 169-173

Nicol, S., Stolp, M., Hosie, G. W. (1991). Accumulation of fluorescent age pigments in a laboratory population of Antarctic krill (Euphausia superba Dana). J. exp. mar Biol. Ecol 146: 153-161

Quetin, L., Ross, R. M. (1991). Behavioural and physiological characteristics of Antarctic krill Euphausia superba Dana. Am. Zool. 31(1): 49-63

Rosenberg, A. A., Beddington, J., Basson, M. (1986). Growth and longevity of krill during the first decade of pelagic whaling. Nature 324(6093): 152-154

Thomas, P. G., Ikeda, $T$ (1987). Sexual regression, shrinkage, re-maturation and growth of spent female Euphausia superba in the laboratory. Mar. Biol. 95: 357-363

Manuscript first received: May 27, 1992

Revised version accepted: October 30,1992 